ARKADIUSZ ŚWIADEK

KATARZYNA

SZOPIK-DEPCZYŃSKA

\title{
Industrial chains \\ and innovation activity in \\ Małopolska region \\ in 2008-2010
}

Professor Arkadiusz Świadek

University of Zielona Góra

Ph.D. Katarzyna Szopik-Depczyńska Univeristy of Szczecin

\section{Introduction}

Currently, in literature there is a belief that traditional determinants of the comparative advantage have lost their significance in the perspective of the last thirty years as a result of the globalisation processes and computer or telecommunications revolution (Audretsch 1998, p. 19). It is believed, moreover, that these factors explain the variability of the economic development on the macro level in the dissatisfactory level. Research carried out by R. Solow (after: Stough 1998, p. 1) showed that almost half of the economic development was not adequately explained due to traditional causes. This phenomenon was considered the error of variance and was defined as the influence of technological changes. On this basis, innovations became the autonomous, the most important accelerator of the long-term level of the competitiveness of the economy.

According to "The Economist" low costs in communication are connected with overcoming the distance will constitute one of the most important factors influencing the shape of the society of the first half of the XXI century. A significant increase of the meaning of the innovative activity is documented by 
the increase in patent applications and granted patents in the United States from the level of the average 40-60 thousand in the XX century, to more than 120 thousand in 1985 and the significant decrease of the demand for the low-skilled employees (Kortum, Levner 1997, p. 1).

Although geographically the market of most products is subject to globalisation, we can also observe the increase of the meaning of the innovative activity in economically advanced countries. This is interpreted as the result of the increased role of regions being the key sources of the competitive advantage (Audretsch 1998, p. 26). On one hand, the resource recognition of technology is becoming international, and on the other the importance of the regional systems is growing due to the spatial approximation and the process of knowledge flow within and between them (Guerrieri 1999, p. 154). What's more, the meaning of the regional level in such countries is growing in parallel to their technological advancement (Beaudry, Breschi 2003, p. 339). Along with the globalisation, and perhaps in its effect, there is a belief that the innovative activity is less associated with transnational corporations, and more often with highly technological innovative regional clusters (Audretsch 1998, p. 18). On this basis, there arises a doubt: whether and to what extent are the discussed phenomena occurring in the economically developed countries adequate for the countries on the lower level of development, and the solutions used there can be used for the direct transfer?

The process of reducing the economic gap is not automatic and dependent on the abilities of the countries in reducing the technological gap. The concept of "social skills" of M. Abramowitz (1994) implies the ability of the country to carry solutions created beyond the borders of the country, as a result of the phenomenon of dynamic spread of absorption skills of the imported technologies. Moreover, developing countries may be characterised by dynamic structural changes in the short run, if they can build their absorption and imitation skills. Nonetheless, sooner or later they will face the imperative of the creation of own scientific and technological base (Abramowitz 1994). However, before this happens, countries of this type are forced to overcome the spatial barrier to reduce the existing economic disparities.

The essence of the functioning of the innovation systems are relations taking place between particular participants of the market creating the network of links. They can take on the nature of vertical and/or horizontal interactions, where the spatial and technological close-up play an important role (Fischer 2001, p. 211, Bouncken 2011).). Because of the high degree of complexity of the matter discussed in this paper it was decided to examine only the vertical links, that 
is relations with the suppliers and recipients of goods and services produced in industrial systems.

Modern regional networks aim at diversifying relations by creating relationships with other groups of enterprises in the supply chain (Jüttner, Christopher, Baker 2007, p. 377-392; Brdulak 2011).. In traditional systems, such interactions should hover around the sublime dependencies connected to the problem of specialisation. At this point of deliberations it is interesting whether the innovative activity of regional systems in Poland is conditioned by: diversified or narrow interactions; taking place in small or large distance; based on strong and permanent, or loose relations between enterprises.

The developed conceptual framework prompted the analysis of the problem of the influence of the relations of enterprises within the supply chains on the innovative activity of the industrial system in Lesser Poland. The principal research hypothesis is the statement that the innovative processes found in the national industrial systems are strongly determined by the intensity and character of the vertical relations along the supply chain. They include the number of industrial suppliers and recipients, or the existence in the full supply chain. The ability of the proper identification of innovative processes with their limitations in the examined province creates the foundations to create the adequate mechanisms in the area of stimulating the innovative networks.

The primary objective of the conducted research was to search for the influence of the number of industrial interactions occurring between the enterprises in the supply chain on the innovative activity of the researched regional system. The consequence of the conducted analyses will be the determination of the boundary conditions for the structure of the regional innovation network, which will take into account the specificity of the researched region.

The research sample includes 500 enterprises from the province of Lesser Poland, which is one of the regions representing the medium strong level of the industrial development in Poland. Analyses were performed based on the survey questionnaire. The basic method of data collection included the path connecting the telephone conversation with sending the survey questionnaire by e-mail or mail.

\section{The methodology of the conducted studies and characteristics of the research sample}

The indicators prepared for OECD countries focus on traditional input and output elements. They are standardised in most OECD countries, what 
allows for the utilitarian interregional and international comparison (OECD 2005). On this basis it was decided to adopt the following dependent variables for the study: financial expenditure incurred on the innovative activity, implementation of new products and processes, institutional innovative cooperation. On the side of independent variables, from the point of view of the formulated main research goal, we can find: the number of industrial suppliers and recipients.

One of the methods of the analysis of the quality variable is the determination of chances, with which its variant can occur in the future depending on the adopted factors - probit modelling. Although the number of variants may be substantial, this paper will use only the method of estimating parameters of the binary variables, that is two variants. This results from the meaning and purpose of the conducted analyses.

Due to the use of one factor probit models in order to interpret the studied phenomena, the structural form of the model is enough, which may be enriched by the likelihood values. The sign occurring by the parameter is crucial for the deliberations. The positive one means that chances that the analysed innovative event will take place is statistically higher in the studied group of objects compared to the remaining collectiveness. The negative one is interpreted the other way round. The probit modelling used in the paper allows to conduct research on the regional systems because of the requirement to have quantitatively significant, but statistical, samples, where the dependent variable is in the quality form.

To achieve the research objective it was necessary to estimate more than three hundred various probit models, from which some met the required statistical conditions and the deliberations of the paper focused on them.

Industrial relationships are recognised as the major determinant of the innovative activity of enterprises understood as the expression of cooperative relations. So far, studies accomplished by the authors conducted in the country reinforce the belief that interactions found in the industry strongly influence the ability to generate new products. In other words, vertical ties should result in the stimulation of the innovative activity in regional industrial systems in Poland, both for the suppliers and the recipients.

As it has already been mentioned in the introduction, the study was conducted based on the sample of 500 industrial enterprises of the Lesser Poland province. 
Table 1. Structure of industrial enterprises from the point of view of the level of the used technology and size in the Lesser Poland province in the years 2008-10 (in percentages)

\begin{tabular}{c|c|c|c}
\hline Level of technology & Lesser Poland province & Size of the enterprise & Lesser Poland province \\
\hline High & 5,4 & Micro & 46,2 \\
\hline Medium-high & 7,6 & Small & 33,8 \\
\hline Medium-low & 25,4 & Medium & 16,0 \\
\hline Low & 61,6 & Large & 4,0 \\
\hline
\end{tabular}

Source: own study based on own research

Both in case of the size of enterprises and the applied technology their structure is at the similar level to the national data.

\section{The influence of industrial relations on the innovative activity of enterprises}

Technological structure of the studied enterprises corresponded to the one analysed by the CSO. There dominated the subjects representing the low technological level $(61,6 \%)$ and the medium-low one $(25,4 \%)$. A small part included those from the medium-high $(7,6 \%)$ and high technologies $(5,4 \%)$. The greatest number are: publishing activity (76 enterprises), manufacturing of the metal products (66 subjects), foodstuffs (55 enterprises) and furniture (55). Approximate types of activities constitute the total of $50,4 \%$ of the sample.

The test subjects indicated the broad relationship with the industrial suppliers (761 cases), what means about 1,5 relations per enterprise. Their technological structure is changing significantly. The importance of low technologies is decreasing to $42,7 \%$. While the others are gaining: medium-low to $35,3 \%$, medium-high to $14,6 \%$ and high technologies to $7,4 \%$. In the first line there is the metal production (78 associations), textiles (70 associations), products from other non-metallic minerals (68 associations), rubber and plastic products (61 associations), metal products (59 associations), made of wood (59 associations). Others play a small role in the studied industrial system. Although the technological structure to the region suppliers is improving, they are still the domain of areas with low technological advancement. 
Models with statistically important parameters were generated for eleven from eighteen potential variables, so they concerned more than half of the accepted areas of innovation. To a similar extent there were described the particular considered surfaces: implementation, financial and cooperative.

Table 2. Probability of the occurrence of particular areas of innovative activity in the Lesser Poland region from the point of view of the number of industrial suppliers

\begin{tabular}{|c|c|c|c|c|}
\hline \multirow[b]{2}{*}{ Innovation parameter } & \multirow{2}{*}{$\begin{array}{l}\text { Suppliers } \\
\text { (number) }\end{array}$} & \multirow[b]{2}{*}{ Probit form } & \multicolumn{2}{|c|}{ Probability } \\
\hline & & & $\begin{array}{c}\text { relevant } \\
\text { event }\end{array}$ & $\begin{array}{c}\text { contrary } \\
\text { event }\end{array}$ \\
\hline Expenditures on $B+R$ activity & 4 & $y=-0,48+1,09 x$ & 0,62 & 0,35 \\
\hline Investments in the fixed assets & 4 & $y=0,71+0,63 x$ & 0,33 & 0,21 \\
\hline - into machines and equipment & 4 & $y=0,50+0,67 x$ & 0,38 & 0,24 \\
\hline Computer software & 4 & $y=0,18+0,52 x$ & 0,46 & 0,33 \\
\hline Implementation of new processes: & 4 & $y=0,53+0,64 x$ & 0,37 & 0,24 \\
\hline - by-production systems & 4 & $y=-0,56+0,75 x$ & 0,64 & 0,45 \\
\hline - support systems & 4 & $y=-0,83+0,79 x$ & 0,49 & 0,30 \\
\hline Cooperation with suppliers & 4 & $y=-0,85+0,66 x$ & 0,70 & 0,55 \\
\hline Cooperation with recipients & 4 & $y=-1,99+0,65 x$ & 0,21 & 0,12 \\
\hline Cooperation with recipients & 4 & $y=-0,91+0,48 x$ & 0,71 & 0,61 \\
\hline Total innovative cooperation & 4 & $y=-0,38+0,65 x$ & 0,59 & 0,43 \\
\hline
\end{tabular}

Source: own study based on studies

Financing new solutions in the analysed industrial system is strictly connected with the occurrence of the industrial relations in the region. The occurrence in the Lesser Poland province of the network relations from the production suppliers determines the creation of new technological solutions. Their characteristics is close both to the direction and intensity. This influences the introduction of unambiguous conclusions in the analysed area. 
Innovative activity in this case is growing when the greater number of diverse industries maintains contacts with the studied subjects - models with four suppliers occurred in all surfaces of innovation. For the remaining seven surfaces the connections with the suppliers remained without significant statistical correlations.

In other words: the fact of cooperation with industrial suppliers, regardless of their affiliation to a particular PKD group, is a sufficient condition foe the increased dynamism of the innovative system. The ongoing technological diversification and the increase of the number of industrial relations are additionally accelerates the discussed processes in the system.

On the side of the recipients, enterprises have weaker industrial solutions. They drop four times in comparison to the suppliers - with the number of events on the level of 183 - what is interpreted as the unfavourable event, but typical. And in this case we can observe positive changes in the structure of technological solutions. A significant decrease was noted for the enterprises operating in the area of low technologies (32,4\% associations). A slight increase of the role can be attributed to the area of medium-low technologies (29,1\% associations). There was a significant increase of meaning of industries from the scope of medium-high technologies (34,6\% associations five time increase) and there was a slight decrease of the number of associations in the area of high technologies $(3,8 \%)$. Despite the weak potential calculated by the number of contacts with industrial recipients, we can observe positive changes describing the studied relations, what has a positive influence on the system innovative activity. The first place in the ranking is occupied by the production of machines and equipment (22 associations). Then, there is the production of mechanical vehicles (15 associations) and metal ready products (15 associations). Based on the above data it can be stated that enterprises located in the region are often an element of the industrial chain also on the recipient side, although with much less intensity. What is positive is the fact that in these couplings at start there are mostly manufacturers from the medium-high areas of technology. A small role is noted for the most technologically advanced enterprises, what proves the weak developmental potential of the region in this area and at the same time indicates the typical civilisation backwardness of the national provinces - embryonic level of the system development of high technologies. 
Table 3. Probability of the occurrence of particular areas of innovative activity in the Lesser Poland region from the point of view of the number of industrial recipients

\begin{tabular}{|c|c|c|c|c|}
\hline \multirow{2}{*}{ Innovative parameter } & \multirow{2}{*}{$\begin{array}{c}\text { Re- } \\
\text { cipients } \\
\text { (number) }\end{array}$} & \multirow[b]{2}{*}{ Probit form } & \multicolumn{2}{|c|}{ Probability } \\
\hline & & & $\begin{array}{c}\text { relevant } \\
\text { event }\end{array}$ & $\begin{array}{c}\begin{array}{c}\text { contrary } \\
\text { event }\end{array}\end{array}$ \\
\hline Expenditures on $B+R$ activity & 3 & $y=-0,48+1,09 x$ & 0,62 & 0,35 \\
\hline Investments in the fixed assets:: & 2 & $y=0,70+0,48 x$ & 0,33 & 0,24 \\
\hline - buildings and constructions & 2 & $y=-0,83+0,53 x$ & 0,42 & 0,30 \\
\hline - in machines and equipment & 2 & $y=0,49+0,50 x$ & 0,38 & 0,27 \\
\hline Implementation of new products & 4 & $y=0,50+1,04 x$ & 0,38 & 0,18 \\
\hline Implementation of new processes: & 4 & $y=0,54+1,00 x$ & 0,37 & 0,18 \\
\hline - creation methods & 4 & $y=-0,09+0,77 x$ & 0,52 & 0,34 \\
\hline - by-production systems & 3 & $y=-0,56+0,75 x$ & 0,64 & 0,45 \\
\hline - support systems & 1 & $y=-0,84+0,41 x$ & 0,39 & 0,30 \\
\hline Cooperation with suppliers & 4 & $y=-0,83+0,67 x$ & 0,70 & 0,54 \\
\hline Cooperation with higher schools & 4 & $y=-2,08+0,93 x$ & 0,24 & 0,11 \\
\hline Cooperation with national JBR & 2 & $y=-1,63+0,79 x$ & 0,30 & 0,16 \\
\hline Cooperation with recipients & 3 & $y=-0,92+0,57 x$ & 0,71 & 0,59 \\
\hline Total innovative cooperation & 4 & $y=-0,37+0,85 x$ & 0,60 & 0,38 \\
\hline
\end{tabular}

Source: own study based on research

Enterprises included in the intermediate link of supplies in the industrial chain are characterised by significantly higher innovative activity in the regional system. This reinforces the thesis about the importance and imperative of the existence of strong industrial relations on the side of recipients regardless of their sector affiliation, or the physical distance. The observed regularities are connected with fourteen variables out of eighteen considered ones adopted for the study, and thus even more often than in case of industrial suppliers. However, if we take into account a much smaller number of relationships 
with the recipients, the scale of the system positive impact is lower than it could be.

The estimated models prove, just like in case of the suppliers, that the growing number of industrial recipients influences the acceleration of innovative processes in the region. Lesser Poland is included in the group of strong industrial systems in the country. Because of that, in contrary to economically weaker cases, the meaning of vast industrial affiliations is growing.

Summing up, the growing intensity and diversity of industrial relations in the supply chains in the Lesser Poland region, on the side of suppliers and recipients, has a positive impact on the frequency of the implementation of new solutions, although the analysed case enters into strong industrial relations only with the national and international networks, often being one of their elements, but not the final manufacturer.

The case of the studied province indicates the imperative of the occurrence of the diversified and common interactions taking place between the regional industrial system and its further surroundings, considered the channel of innovation transfer to and from the region. Although the number of suppliers and industrial recipients does not fundamentally differ from the one observed for other provinces, the technological structure observed there is definitely more favourable. On the other hand, the indicated regularities suggest the necessity for the common and diversified entering into relations of cooperation with the industry in order to improve the dynamics of the innovative processes in the region.

\section{Conclusion}

The primary objective of the study was to search for the influence of the relations of the industrial enterprises along the supply chain on the innovative activity of the regional industrial system of Lesser Poland. The consequence of such formed goal is the formulation of the boundary conditions for the regional network of innovation, which takes into account the specificity of the studied case.

The obtained final results indicated that the participation of the analysed industrial enterprises in the supply chain, both in case of the suppliers and recipients, positively determines the acceleration of the innovative processes in the regional system. The occurrence in Lesser Poland of the supra-regional - national and international, relations with the network character between the production enterprises contributes to the creation of new technological solutions, 
and their approximate intensity influences the possibility to derive interesting conclusions. Analysing the industrial suppliers the innovative activity of the region increases, with the higher number of the maintained contacts. Thus, the diversification processes have a significant influence on the information sources on new technological solutions. The fact of cooperation with the industrial suppliers, regardless of their affiliation to particular PKD group, is the condition sufficient for the improvement of the innovative dynamism of the system. While the progressive diversification and increase of the intensity of the industrial relations accelerates the analysed processes.

In parallel, only small, but growing, number of industrial recipients accelerates the innovative activity in the province. The mere fact that also the recipient should act in the industry is the condition sufficient to stimulate the innovative activity of the enterprises. This probably results from the fact that the market needs are more positively identified and they do not require expensive research. On the side of the relations with the industrial recipients the thesis closer to the truth is the statement that the meanwhile specialised interactions are the main element influencing the current innovative attitudes in Lesser Poland, but at the same time they are guided to the arrangement of the diversified character.

The presented article pays attention to the fact that only enterprises operating in the integrated industrial network, often with the transnational scope, can intensively introduce the innovations. In general, the more often, the greater number of the cooperating subjects, both in the input and the output. Thus, the phenomenon of the vertical cooperation constitutes the basis for the possibility of the knowledge transfer to the regional industrial system.

\section{Summary}

The importance of industrial linkages for the enterprises' innovation activity in Małopolska region 2008-2010

The main objective of the study was an attempt to search for the conditions affect the nature of supply chains for enterprises innovative activity within the regional industrial systems, and consequently determine the frame conditions for the model of regional innovation networks, taking into account the specificities of Małopolskie region. The study was based on a questionnaire on a group of 500 companies from Małopolska. The study used probity modeling. This method is an effective research tool for large, but the static tests in which the dependent variable has a qualitative character. 
Key words: innovation, region, supply chain, industry.

\section{Streszczenie}

Znaczenie powiązań przemysłowych dla aktywności innowacyjnej przedsiębiorstw $\mathrm{w}$ regionie małopolskim $\mathrm{w}$ latach 2008-2010

Głównym celem prowadzonych badań była próba poszukiwania zmiennych warunków wpływu łańcuchów dostaw na działalność innowacyjną przedsiębiorst $\mathrm{w} w$ obrębie wybranego regionalnego systemu przemysłowego, a tym samym określenie warunków brzegowych dla modelu regionalnej sieci innowacji, biorąc pod uwagę specyfikę województwa małopolskiego. Badanie zostało oparte na kwestionariuszu ankietowym i wykonane na grupie 500 firm z Małopolski. W badaniu wykorzystano modelowanie probitowe. Metoda ta jest skutecznym narzędziem analizy dużych, ale statycznych prób, w których zmienna zależna ma charakter jakościowy.

Słowa

kluczowe: innowacja, region, tańcuch dostaw, przemyst.

\section{References}

1. Abramowitz M. (1994), The origins of the post-war catch up and convergence boom, in: J. Fagerberg, N. von Tunzelman, B. Verspagen (eds.), The dynamics of Technology, Trade and Growth, London.

2. Audretsch D.B. (1998), Agglomeration and the location of innovative activity, "Oxford Review of Economic Policy", Vol. 14, No. 2.

3. Beaudry C., Breschi S. (2003), Are Firms in Clusters Really More Innovative?, "Economy. Innovation. New Technology", No. 12(4).

4. Bouncken R.B., Supply Chain Contingencies: The Effects of Up-Stream Directives on Supplier's Innovation Performance, "Engineering Management Journal" 2011, Vol. 23, No. 4.

5. Brdulak H., Łańcuchy dostaw w warunkach niepewnej gospodarki. Trendy światowe $i$ wnioski z Polski. w: Funkcjonowanie tańcuchów dostaw: aspekty logistyczne, przykłady branżowe, red. nauk. H. Brdulak, E. Duliniec, T. Gołębiowski, ZN nr 31, Kolegium Gospodarki Światowej, SGH, Warszawa 2011.

6. Fischer M.M. (2001), Innovation, knowledge creation and system of innovation, "Annual Regional Science", No. 35. 
7. Guerrieri P. (1999), Patterns of national specialisation In the global competitive environment, in: D. Archibugi, J. Howells, J. Michie (eds.), Innovation Policy in a Global Economy, Cambridge University Press, Cambridge.

8. Jüttner U., M. Christopher, S. Baker, Demand Chain Management-Integrating Marketing and Supply Chain Management, "Industrial Marketing Management" 2007, Vol. 36, No. 3.

9. Kortum S., Levner J. (1997), Stronger Protection or Technological Revolution: What is Behind the Recent Surge In Patenting? Working Paper No. 6204, National Bureau of Economic Research, Cambridge.

10. OECD (2005), Podręcznik Oslo. Zasady gromadzenia i interpretacji danych dotyczacych innowacji, Wydanie trzecie, OECD, Paryż.

11. Stough R.R. (1998), Endogenous growth in a regional context, "Annals of Regional Science", No. 32. 